\title{
Sir Syed Ahmad Khan: The First Historical Archaeologist
}

\section{Lubna Irfan*}

\begin{abstract}
The field of historical archaeology has been developed extensively in the modern period, specifically in the $20^{\text {th }}$ century. Despite this, it is seen that the method and technique of historical archaeology has been put to use by Sir Syed Ahmad Khan, a century earlier. The paper looks at his monumental work Asar-us-Sanadeed as the first work on historical archaeology composed in India. In the work Sir Syed Ahmad Khan utilises the information gained by him through his extensive surveys at Delhi and in addition he uses the knowledge garnered from historical and literary sources, in the process he corroborates the information gathered from both the sources, and thus fulfils the criteria of historical archaeology.
\end{abstract}

Keywords: Sir Syed Ahamd Khan, Historical Archaeology, Asar-us-Sanadeed, Surveys, Architecture, Mughal history, Delhi, History of Delhi

*Research Scholar, Centre of Advanced Study, Department of History, Aligarh Muslim University, Aligarh, India 
The founder of Aligarh Muslim University has been identified as a reformer, an educationist, a visionary, an essayist, a journalist and a government servant, but there is one aspect of his personality that has been relatively less highlighted and explored and surprisingly much less worked upon, that of him being a historian. Christian Troll, C.M.Naim, I.H. Siddiqui and Nazir Ahmad are the few people who have tried to explore this aspect of Sir Syed's work and personality. After studying the historical works of Sir Syed, he not only appears to be an erudite and learned historian but because of the techniques utilized in his work Asar-us-Sanadeed he can also be identified as the first Historical archaeologist of India. Much before the arrival of Cunningham ${ }^{1}$ and Sir John Marshall ${ }^{2}$ on the scene of the historical explorations of India, Sir Syed Ahmad Khan was conscious of the scientific study of the past. He recognized the importance of the proper survey, exploration, measurement and documentation of the material remains of the past and the significance of relating the information from these material remains with the available historical sources. Before going further it would suffice here to establish the context in which earlier works have looked at Sir Syed's historical endeavours.

1. Christian Troll, in an article on various aspects of Asar-us-Sanadeed takes the differences in the two editions of the work published in $1847 \mathrm{CE}$ and 1854 $\mathrm{CE}$ as the main subject matter of his enquiry. His argument is that, the former edition contains many peculiar characters of the pre-modern Persian history writing tradition while the latter resembles the modern historiographical tradition which was being developed and furthered during the British era. Troll further goes on to elucidate the reasons behind these shifts. $^{3}$

2. Another important work that has been undertaken on the historical works of Sir Syed Ahmad Khan is by C.M. Naim. He also highlights the importance of difference between the two 'books' called Asar-us-Sanadeed. In addition to looking into the aspect of the reason of the change in style and the authorship of the book, Naim also tries to explore the target audience that was to receive these texts and the response received by the work. ${ }^{4}$

3. Apart from these works, Iqtidar Husain Siddiqui has written a paper on Sir Syed Ahmad Khan's approach to History writing, there he has dealt with a host of works undertaken by Sir Syed both before and after the revolt of

1 Cunningham, Alexander, Sir Alexander Cunningham and the beginnings of Indian archaeology, Dacca, Asiatic Society of Pakistan, 1966

2 Marshall, John, A guide to Taxila, Cambridge University Press, London, 1960

3 Troll, Christian W. , 'A Note on an Early Topographical Work of Sayyid Ahmad Khan: Asar Al Sanadid', The Journal of the Royal Asiatic Society, 1972, No. 2, pp. 137-143

4 Naim, C. M., 'Syed Ahmad and His Two Books Called 'Asar-al-Sanadid', Modern Asian Studies, 2010, pp.1-40, p. 15 
1857. He also gives details of the archaeological material collected by Sir Syed. ${ }^{5}$

4. Nazir Ahmad, another scholar, in a paper, has tried to highlight the archaeological significance of Asar-us-Sanadeed. He not only deals with the questions taken up by the previous scholars regarding the text, but tries to give details of the references made in the text to various historical sites; furthermore he dwells in the controversy regarding the historical slabs installed at the Aligarh Mosque. 6

Thus there has developed important scholarship around the text Asar-us-Sanadeed and its two different versions and their relevance for that period. There however is a need for a detailed analysis of the content of Asar-us-Sanadeed itself, and to bring forth the techniques and methods utilized by Syed Ahmad in analysing the material remains and in contextualising that data with the historical sources, this paper would attempt at doing just that. It would, with examples from the text, look at Sir Syed Ahmad Khan as the first historical archaeologist in India. In addition to this, the paper would also attempt to put into perspective the significance of this historical work during the colonial period, since the text is not simply a description of some buildings of Delhi but it acts as a forgotten moment in the historical development of the indigenous mind. It exists as a criticism to the colonial argument of native ignorance towards its own past. 7 This aspect of the importance of Asar-us-Sanadeed as an example of historical consciousness of the native population will also be dealt with in the paper.

Before dwelling on the nature of Sir Syed's history writing, the definition of the term historical archaeology needs to be stated in order to understand why Asar-usSanadeed can be called a work of historical archaeology. Historical Archaeology basically means studying and understanding material remains of the past through information from historical sources ${ }^{8}$, thus it becomes relevant only for the historical period, moreover when this technique is applied to a site of medieval period it has been referred to as Medieval Archaeology. ${ }^{9}$ Having said this, Asar-us-Sanadeed becomes an important point of departure for historical archaeology in India because

5 Siddiqui, Iqtidar Husain, 'Sir Syed Ahmad Khan's Approach to History and History Writing', published in Sir Syed Ahmad Khan: A Centenary Tribute, ed. Asloob A. Ansari, Adam Publishers, Delhi, 2001, pp. 106-127

6 Ahmad, Nazir, 'Sir Syed Ahmad Khan's Works on Archaeology Entitled Athar-us-Sanadid: A Study', published in Sir Syed Ahmad Khan: A Centenary Tribute, ed. Asloob A. Ansari, Adam Publishers, Delhi, 2001, pp. 128-153

7 Singh, Upinder, The Discovery of Ancient India: Early Archaeologists and the Beginnings of Archaeology, Permanent Black, Delhi, 2004, p. 290

8 Harrington, J. C., 'Archaeology as an Auxiliary Science to American History', American Anthropologist, New Series, Vol. 57, No.6, Dec. 1955, pp.1121-1130

9 R.N.Mehta, Medieval Archaeology, Delhi, 1979, p.69 
throughout the book Sir Syed describes various architectural remains of Delhi and its environs and provides historical context to those remains by references from historical sources regarding their social, cultural and political nature.

Asar-us-Sanadeed is the work which would primarily be analysed in this paper to highlight the historical endeavours of Sir Syed, yet this wasn't the only work on history that was attempted by him, a brief overview of some of his other historical works needs to be given before going further. Being the witness to and a part of the last generation of the Mughal nobility and its grandeur, Sir Syed must be viewed in the context of what made him a man of a historical vision. Educated in several traditional sciences, Sir Syed had always been a curious student. Furthermore his interest in History is evident from the choice of the subject matter for his books. One of these works was Jam-i-Jam, a work on the bygone rulers of Delhi from the time of Timur; the importance of this work is highlighted in the fact that it for the first time gave the date of Sher Shah's birth. 10 Moreover, Sir Syed before publishing the second edition of Asar-us-Sanadeed had already compiled a list of kings who ruled Delhi during the last five thousand years; this list began with Raja Yudhishtra and culminated in the name of Qaisar-i-Hind Empress Victoria (Silsilat-i-Mulook). ${ }^{11}$ The list of names contains around 202 names of rulers with that of their fathers, their year of accession, their capitals and the duration of their reigns. Another historical work that Sir Syed undertook but that has now been lost was the history of Bijnore that he compiled during his tenure as Sadr Ameen there. This work, composed in 1855, was at the office of the Sadr Board when the revolt took place and in the revolt the manuscript was lost. ${ }^{12}$ Sir Syed is also credited with revising the text of Ain-iAkbari. This particular book was identified by him as a text of utmost historical importance and the absence of a proper version available for further study left him with the task to collect several copies of the work and compare them and arrive at a properly compiled revised and edited text of Ain-i-Akbari, which still had some shortcomings yet the fact that Sir Syed produced a glossary of the unfamiliar words of Persian, Arabic, Turkish, Hindi and Sanskrit and explained the terms prevalent during Akbar's period shows his keen interest. Interest of Sir Syed in visual history also comes out in the fact that he got Ain illustrated with the help of some famous artists of Delhi. Thus this not only points to the fact that Sir Syed recognized the importance of historical content but also that he wanted to make historical texts available in a way that it can be conducive for future research as well. Not only Ain-iAkbari, but Tarikh-i-Firozshahi and Tuzuk-i-Jahangiri were also edited and revised by Sir Syed. ${ }^{13}$ Apart from these works, there were two important works composed by Sir Syed following the revolt of 1857. Tarikh-i-Sarkashi Zila Bijnore and Risala

$10 \quad$ Siddiqui, p. 107

11 Hali, Khvajah Altaf Husain, Hayat-i-Javed : a biographical account of Sir Sayyid, translation, K.H. Qadiri \& David J. Matthews, Idarah-i -Adabiyat-i-Delli, Delhi, 1979, p.27

Ibid, p. 28

Siddiqui, p. 124 
Asbab-i-Baghawat-i-Hindustan form important points to understand the changing nature of historical understanding of Sir Syed Ahmad Khan. ${ }^{14}$

Regarding the techniques of writing used by Sir Syed, it can be stated with some reservation that the critical approach that today defines the subject of History ${ }^{15}$ was at some level being put to use by Sir Syed to come to truthful conclusions. He laboured to collect most of the sources on any available topic and cross-check them with each other to come to honest results. To give an example, while revising the $2^{\text {nd }}$ volume of Ain-i-Akbari, Sir Syed was faced with a serious problem because the section on Ain-i-Kharaj was different in all the copies of the Ain that Sir Syed had and this meant that there was no means to come to the correct information. At this time, a book written during Sir Syed's maternal grandfather Nawab Dabirud Daula's time came to light, which had a detailed and accurate account of the revenue of the Mughal emperors and Sir Syed copied the account of Akbar's reign and included it in his second volume of Ain-i-Akbari. ${ }^{16}$ Another important historical source that has been revised and published under Sir Syed's name is the work Tarikh-i-Firoz Shahi, a reliable and authentic history of the Sultanate period. This work was done during Sir Syed's posting at Moradabad around 1860 AD. The dedication of Sir Syed is visible in his laborious endeavours of collecting four different copies of Tarikh-iFiroz Shahi from Imperial Library, Delhi, from Mr. Elliot, Mr. Edward Thomas and from Benares and using them to revise his own copy of Tarikh-i-Firoz Shahi before sending it for publication by Asiatic Society of Bengal. ${ }^{17}$ Still it has been argued that both these texts have several errors due to the limited number of versions of manuscripts available, and several mis-readings have been done in these works on the part of Sir Syed, which needs to be acknowledged and stated. ${ }^{18}$

Despite all his shortcomings, Sir Syed Ahmad Khan was a pioneer in the field of working on Antiquities of Delhi. His idea of writing a book on the physical structures left behind at Delhi and not just describing them but measuring them with diligence and then relating them to the larger political and social fabric of the time appears a unique measure. Efforts of such sort had not been made in this manner ever before. Though Christian Troll in his essay argues that Asar-us-Sanadeed was written and

14 For details about these works see, Z.U.Malik, 'Historical Writings of Sir Syed Ahmad Khan on the Indian Revolt, 1857-1859',published in Sir Syed Ahmad Khan: A Centenary Tribute, ed. Asloob A. Ansari, Adam Publishers, Delhi, 2001, p. 128-153

15 Chris Lorenz, 'Scientific/Critical Historiography', in: Aviezer Tucker (ed.), Blackwell Companion to Philosophy of History and Historiography, Blackwell: Oxford 2008, p.393403, p. 393

16 Hali, p. 30

17 Ibid, p. 58

18 Irfan Habib in a lecture at CAS Department of History, Aligarh Muslim University refers to the issue of misreading various words on part of Sir Syed, for example the use of the word jagir in the revised version of Tarikh-i-Firoz Shahi which wasn't current during the Sultanat period. 
conceived in the manner of earlier topographical and biographical writing in Persian, yet there are no references given to the earlier works on similar lines except for one, Sair-al-Manazil. Irfan Habib argues that there was no earlier tradition in Persian of a book about old buildings and their inscriptions ${ }^{19}$, thus making Sir Syed's effort a path-breaking one in the field of historical archaeology. One also needs to keep in mind that during the time when this work is being composed, neither the field of archaeology, and much less the field of historical archaeology had developed in its proper form in India, thus this work can be understood as a precursor to those subjects which were being formulated in $19^{\text {th }}$ century India. It has been argued that the primary location for the ones interested in the study of subjects termed as Indology, antiquarian studies and archaeology during the colonial period was the Asiatic Society of Bengal which still at that time was reluctant towards Indian members. ${ }^{20}$ In an intellectual space contested between the traditional methods of history writing and the newly emerging colonial scholarship on Indian past, Asar-us-Sanadeed's first edition appears unique, in the way that it brings forth the study of antiquarian remains which is something completely divorced from traditional Indo-Persian historiography, and at the same time it also incorporates the tazkira tradition of providing biographies of famous personality of the city which is something that is prevalent in Persian historiographical tradition, thus by attempting to bring these two aspects of history writing together, Asar-us-Sanadeed becomes a one of its kind endeavour.

In the first edition of Asar-us-Sanadeed, the first chapter describes the buildings outside the walled city; the second, the Fort and the structures within it; the third, the walled city of Shahjahanabad; and the fourth the people of 'Dilli', this organization can be considered as an exercise of studying history in totality, studying history as a whole with physical remains, historical accounts, structures, traditions, the people and their memories and customs all coming together to develop a three dimensional picture of the past. The second edition of Asar-usSanadeed has been called a different book altogether, it has some basic differences from the first edition and this has generated major scholarship around the book. In the second edition, the first chapter of the book is new and refers to a brief history of the first population of all India, the second chapter contains the full account of the Fort, the fortresses erected ever since the city of Delhi, the details of the $1^{\text {st }}$ and the $3^{\text {rd }}$ chapter of first edition are present in $3^{\text {rd }}$ chapter of the second edition, the second edition also contains improvement in the content and details of the buildings described according to the author. ${ }^{21}$

Nazir Ahmad has argued that the addition in the second edition is more of historical nature and not of archaeological sort and this makes the second edition an

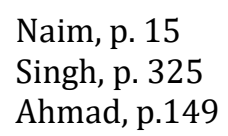


important work of historical archaeology, and it is the second edition that has been primarily consulted for this paper.

Even the techniques Sir Syed utilizes in describing the historical nature of the buildings and spaces appears to be quite historical in the sense that he critically analyses information from various sources, gives space to all the varying divergent accounts and traditions and then systematically debunks the myths and brings out the true historical information, according to his own understanding . To give an example, while describing the establishment of city of Hazratabad in 1418 following the plunder of Amir Timur Sir Syed argues that since at that time no trace of the city Hazratabad was found hence it can be accepted that the area of Hazratabad that is famous in his time might be the original Hazratabad city, here he like a trained historian inserts the remark that this knowledge is current in popular perception and no such information is found in any of the historical books. ${ }^{22}$ It can be seen that Sir Syed's understanding of difference between historical sources and semihistorical accounts informs his work. Furthermore, Sir Syed's emphasis on historical books being the accurate source of historical information comes up at various places across Asar-us-Sanadeed; while analysing the location of Mubarakpur fort and city commenced by Mubarak Shah Hazrat Khan in 1433, Sir Syed first gives the popular perception about the fort and city and says that it is popular that this fort is at the location of the tomb of this very king which is opposite to the tomb of Safdur Jung and because of which that village is popular as Mubarak Shah Kotla, following this Sir Syed gives a counter argument by giving reference to historical accounts and claims that the abovementioned popular assumption is false because it is known that the city of Mubarakpur was established on the bank of the river and during the time of its establishment river didn't flow next to Mubarakpur Kotla, this he proves by giving the fact that there are buildings much older present at that place where the river was supposed to be, thus he finally concludes that according to his calculation and understanding the Mubarakpur fort and city are located at the present location of area Mubarakpur raiti. ${ }^{23}$

Not only is Sir Syed utilizing many sources of information on History to come to the most reasonable truth about the past but he also is utilizing that historical information to deduce means to analyse physical structures. He explores the style and grandeur of architecture of a building to understand the nature of the patron, like he does in the case of Koshak-i-Noor, near Firoz Shah Kotla where he claims that the fine nature of the work on this building reflects that it has been built by a King. ${ }^{24}$ Sir Syed also uses the method of most modern historians of the identification of characteristic features of architectural style to come to the probable dates of the

\footnotetext{
Sir Syed Ahmad Khan, Asar-us-Sanadeed, Sir Syed Academy, Aligarh, 2007, p. 101

Sir Syed, p. 102

Ibid, p.173
} 
monuments, ${ }^{25}$ to take an example, Sir Syed uses his understanding of the architectural features of Afghani style of building activity to come to the conclusion that the Begumpur Masjid belonged to the Pathani (Afghani) style of Architecture and hence to Afghan period ${ }^{26}$. He even gives a systematic description of various constructions works categorized on the basis of monarchs who undertook those construction activities. ${ }^{27}$

Sir Syed knew the importance of archaeological remains and in the case of contradiction of information between historical and archaeological sources he preferred the archaeological ones since it is well know that the material remains are the most truthful of the remains that have come down from history. Hence in the case of contradictions in the dates regarding Asokan era in History books and the inscription on the Ashokan pillar, Sir Syed gives preference to the Asokan pillar as the reliable source of information. ${ }^{28}$ There are many more examples of this kind. ${ }^{29}$

From reading Asar-us-sanadeed it appears that for Sir Syed, history was not devoid of the texture of layers of human existences and the marks they leave behind on the structures. There are innumerable references to structures being described in the process of constant change through construction activity being done on and around them. To give an example Sir Syed mentions Asad Burj as a structure that was damaged by canons during a disturbance and was then reconstructed during the reign of Akbar Shah Second and had been made exactly like the original structure, ${ }^{30}$ this also hints upon a very important aspect in history and archaeology, that of preservation and renovation, and Sir Syed's consciousness about these issues. Sir John Marshall had till then not formulated his minutes regarding the conservation of historical material remains and thus the consciousness on that front seems absent in Sir Syed's historical works. From another example in Asar-us-sanadeeed it appears that Sir Syed appreciated the repair works undertaken at one Sunehri Masjid which had gone to the condition of ruins and was about to crumble when Qazi Muhammad Faizullah Khan Sahab good intentionally repaired it as new, thus the importance of preservation of the historical structures in their original form is something not very relevant to Sir Syed, but he does mention that the history of the mosque was left inscribed on it. ${ }^{31}$

Sir Syed also provides an interesting detail from his architectural analyses of Qutub Minar, He writes that in some history books, Qutb Minar was identified as mosque's minaret which cannot be true because the column's door is north-facing similar to
Singh, p. 334
Sir Syed, p. 178
Ibid, pp.152-160
Ibid, p.144
Ibid, pp. 149-151
Ibid, p. 114
Ibid, pp.229, 232 
Hindu temples, while the doors of minarets are always east facing, like of the pillar begun by Sultan Alauddin Khilji which in accordance to Muslim construction traditions, was located on a plinth as well. This is unlike the Hindus who do not use plinths, a feature also missing from Qutub Minar. Another argument added here is that the structure's first level also shows evidence of bell-and-chain motif of Hindu temples. And from these various facts, Sir Syed argues that the first floor of Qutub Minar is of a Hindu origin and the epitaphs have been inscribed where there were once idols. ${ }^{32}$

In Asar-us-Sanadeed the importance of people for a city is also evident, the texture and depth that develops in history once the actual social and cultural life of people who inhabit the place being described is incorporated, is intriguing, and this was something that was probably recognized by Sir Syed, thus his description of the gates and people on the gateways of the Jami Mosque, Faiz Bazar and Chandni Chowk leaves the reader of Asar-us-Sanadeed awed by the lifestyle that existed in bygone time. There appears an intimate description of the public space that must have been a regular feature of cities across Mughal India; the presence of small vendors selling faluda, kebab, and sugarcane juice at the Southern Gateway of the Jama Masjid of Shahjahanabad adds perspective to the physical structure of the mosque for a historian. Similarly the Northern gate is reported to have magicians and storytellers who must have been recounting the tales of Amir Hamza, Hathim Tai and the Bustan-e-Khiyal for a long time to several generations of people before being observed and recorded by Syed Ahmad. On the Eastern Gateway there is reported, in Asar-us-Sanadeed, the presence of the market of fabric and animal etc. ${ }^{3}$ Similarly the recreation of the beauty of the Chandni Chowk and Faiz Bazar with the description of the beautiful shops that lined them and the causeways that ran through and across these bazaars is also fascinating. ${ }^{34}$

Sir Syed himself appears mesmerized by the physical structures and the effect they produced, he even in his plain and simple style of writing couldn't help but describe the beauty and lively nature of the city that is visible from the top of one the minarets of Jama Masjid. 35

Thus many dimensions regarding the historical approach of Sir Syed come forth on a keen reading of Asar-us-sanadeed.

The work Asar-us-sanadeed also forms an important moment in the understanding of the native historical consciousness. There have been established arguments suggesting that with the development of colonial interest in the Indian past and

Ibid, p.156

Ibid, p. 207-208

Ibid, pp.127-128

Ibid, pp.204-205 
antiquities there was a simultaneous relegation of the Indian population to the position of Ignorant Natives who didn't have historical understanding and consciousness. ${ }^{36}$ The year 1856 formed an important moment in the development of the British attitude towards the Persian texts of the Indian past, and in this light a series of Persian monographs were translated, one of them by Sir Syed himself. ${ }^{37}$ Thus there was an increasing colonial scholarship developing around Indian past, and though there have been native India scholars like Ram Raz (1828) ${ }^{38}$ who had been arguing against the dominant colonial scholarship of foreign influences on the Indian past and along with him Rajendralala Mitra (1877) ${ }^{39}$ who pointed out the flaws in various works done by the British, yet it can be stated that Sir Syed's work Asar-us-Sanadeed formed an important actor in debunking the myth of the ignorance of the local population because it also got itself acknowledged as a source of study by the colonial masters, who took Asar-us-Sanadeed as an authority on the buildings of Delhi. ${ }^{40}$ Syed Ahmad, consciously or unconsciously was undermining the British hegemony over knowledge of Indian past. Though he himself eventually got absorbed in the larger framework of British structures of historical study and survey, yet the fact that Asar-us-Sanadeed was an independent endeavour is an important point to be highlighted.

One thing, however, that needs to be kept in mind while reading Asar-us-Sanadeed is that Sir Syed Ahmad Khan, not only was learning and growing as a thinker but also as a historian, thus there are a lot of differences in the two versions of Asar-usSanadeed, published in 1847 and 1854. Without going into the details, it can be safely stated that while in the former he appears closer to the flowery eulogizing Indo-Persian historical tradition; in the latter he appears closer to the plain, simple, descriptive accounts of the European tradition of history writing. Even the subject matter chosen for the book, that of antiquities, is something which had been developed during the Renaissance in Europe where the physical remains of the ancient Greek and Roman civilizations were studied. It is well known that the target audience of this book also included a large number of Europeans and this fact along with Sir Syed's incorporation in the Archaeological and Historical societies of the time, might have been the reason of the shift in his style of writing. Syed Ahmad was well aware of the interest of colonial officers in India's history and ancient monuments. His first book was even written at the behest of a British judge. He and his brother had purchased manuscripts and made copies of old historical texts for British officers. ${ }^{41}$ Moreover, Sir Syed's developing interest in the field of historical study corresponded with the works being conducted by the British in the arena of
Singh, p.290
Ibid, p. 306
Ibid, p. 311
Ibid, p. 330, 332
Troll, p.141
Naim, p. 12 
acquiring knowledge about the Indian people. It was due to the rising importance of knowing the colonized people and the interesting developments at the Asiatic Society of Bengal, in 1847 the Delhi Archaeological Society was formulated with Hon. J Thomason as its patron and Sir T.T. Metcalfe as the president. Even before Sir Syed became a part of this society in 1852, the publications in the journal of the society were utilizing Sir Syed's Asar-us-Sanadeed's text as an authority on Delhi's monuments. ${ }^{42}$ Furthermore it has been argued that many in the ruling circle took favourable notice of the book. The journal Qiran-al-Sa'dain, published by Delhi College under the supervision of its principal, Dr Aloys Sprenger, remarked: 'This book is excellent and is of great importance to the Society that has been founded at Delhi for the furtherance of researches into the old buildings of the past'. ${ }^{3}$ Thus it can be said that the attempt of Syed Ahmad of retaining the old market, the Indian readers of Urdu, and of capturing the emerging markets of the colonial officers who read Urdu, and European visitors and sightseers in Delhi ${ }^{44}$ was achieved considerably well. Since, Sir Syed soon after the publication of the book became an active member of the Delhi Archaeological Society, and it was in the journal of this society itself that Sir Syed published a pioneering paper on the bricks utilised in construction in India during various time periods. Sir Syed in this paper argues that due to different customs of different ages there are variations in the sizes of the bricks and thus he argues that bricks from the time of Hindu, Pathan, Akbar, Shah Jahan, Mohammad shah and other periods would be different and these can be utilized to understand the age of places where different types of bricks are found. Then he also describes the way he got hold of bricks at the site of Hastinapur where he had to ask his servants to dig 5-6 yards; and the bricks that were found were 20 inches long, 10 inches broad and 21/2 inch thick. Emphasis given by Sir Syed to precise measurement can be noted.

Sir Syed performed the meticulous task of measuring all the monuments and providing the illustrations, sketches and copies of various inscriptions present on the monuments surveyed by him. This does reflect his dedication, yet Sir Syed also has his own shortcomings.

There has been a raging debate regarding the authorship of the first issue of Asar-usSanadeed and there is a well-established argument that the book was actually composed by Imam Bakhsh Sahba'i. C.M.Naim, a leading authority on Asar-usSanadeed argues that most of the Preface, including the panegyrics, was composed by Imam Bakhsh, as was much of the fourth chapter (on the people of Delhi). Their bombast and hyperbole clearly show Imam Bakhsh's involvement. ${ }^{45}$ Furthermore the editions of Ain-i-Akbari and Tarikh-i-Firoz Shahi have been criticised for being

Troll, p.141

Naim, p. 14

Naim, p. 12

Naim, p. 8 
faulty at several places with not proper editing, moreover these historical sources had been worked upon and published before Sir Syed as well, and his work on them was for the most part a reproduction of the earlier works of Gladwin and Qaiser Jahan. Sir Syed's work on Tuzuk-i-Jahangiri, however, is a pioneering one though it was his brother Syed Muhammad who was the one who had a major role to play in this effort, he struggled to get several copies of the text, from the Libraries of the King of Delhi, Raja Raghuband Singh, Nawab Faiz Ali Khan of Jhajjar and several other places. ${ }^{46}$

In a conversation with Prof. Irfan Habib, it was highlighted that in the earlier edition of Asar-us-Sanadeed, Sir Syed doesn't seem to have been conscious of the developments made by James Prinsep in the area of deciphering of the Asokan inscriptions; this is corrected in the later edition of the book. Prof. Habib asserted the point that despite not knowing the meaning of the inscription, Sir Syed diligently reproduced the entire text in the first edition of Asar-us-Sanadeed as well.

It has also been claimed that the subject of the city of Delhi had been worked upon earlier as well, but though the subject matter was worked upon by other people before him yet the historical and the antiquarian context was something that makes Asar-us-Sanadeed a book much superior in content to all the three books written before it, them being, Mirza Sangin Beg's Sair-al-Manazil, Abdul Qadir's Waqai'-iAbdul Qadir Khani (1831) and Zainul Abidin Shirwani's Bustan-al-Siyahat (1834). In the latter two works Architectural and historical details hardly have been given importance and the buildings are described in off-hand manner. ${ }^{47}$ In the former work of Sangin Beg the limited knowledge of the author regarding history and inscriptions leaves the book more of a work of literature than of history. As opposed to that in Asar-us-Sanadeed the detailed copy of the inscriptions on every monument surveyed by Sir Syed are reproduced and sketches of most of the buildings are provided which in itself seems like a great service to the cause of further research work in history.

In Sir Syed one can see a changing attitude towards the idea of history and history writing, there is a serious shift in Sir Syed's consciousness, this becomes evident from the emphasis given to the importance of history in the second edition of Asarus-Sanadeed. Sir Syed in the latter edition explicitly states that the book was a 'history' (tarikh), and was not a mere 'account' (ahwal). ${ }^{48}$ Sir Syed had an established opinion about the way the history should be written, he argues, in one of his speeches in 1864 that the Asian historiography is devoid of the understanding of cause effect relation which forms an important aspect of writing history. He adds

46 Elliot, H.M. and Dawson, J., History of India as told by its own Historians, Allahabad, Vol. 6, p.277

47 Naim, 19

48 Naim, p.26 
that the great scholars who have written histories have written nothing more than panegyrics of the rulers in honour of whom the histories must have been composed. ${ }^{49}$ This argument seems to have been formulated after an engagement with the colonial historiographical traditions and this statement does reflect upon the changes in the nature of two editions of Asar-us-Sanadeed, where the former edition still had the elements of the 'Asiatic Historiography'. Sir Syed's consciousness about history and its relevance is highlighted from some of his other actions as well. He knew the importance of learning in vernacular and he was in touch with other indigenous players in the field who consciously were working towards making knowledge available to the native people. History formed an important subject in that endeavour.50 There are references to publication of translated editions of Rollin's Ancient history of Greece, ${ }^{51}$ Urdu History of Egypt 52 and others. And though it has been relegated to the background but Sir Syed's historical spirit is still alive in various subtle ways at Aligarh Muslim University campus as well. The inscription on the main entrance of the Jama Masjid of the University was originally a part of the Akabarabadi Mosque built during Shah Jahan's reign. After its demolition in 1857 these remains were given by the government to one Mirza Ilahi Bakhsh from whom Sir Syed acquired them and put them up at the Aligarh Mosque. ${ }^{53}$ Though there is a debate regarding the means of acquisition of the panels for the mosque, ${ }^{4}$ yet it has been established that the panels belonged to Shah Jahan's period. The construction of the Mosque also resembles the Shahjahani Mosque architecture. Hence, Sir Syed's historical spirit has been subtly hidden in the construction of AMU where the original MAO college buildings were designed and engineered by Sir Syed himself, and the architecture and layout reflect his historically engrained personality.

\section{Conclusion}

Sir Syed's historical contributions have been positively subsumed by his social and political endeavours and thus there is always a need to remember and revive the critical and dynamic academician in Sir Syed Ahmad Khan. His work Asar-usSanadeed analysed in this paper provides an insight into the material culture of Delhi prior to its destruction and decay following 1857 mutiny, and this further aggravates the importance of Asar-us-Sanadeed. The field of archaeology and even

\footnotetext{
Selected Documents in Aligarh Archives, ed. Yusuf Husain Khan, Aligarh, 1977, p. 43

Selected Documents in Aligarh Archives, p. 274

Selected Documents in Aligarh Archives, p. 42

Selected Documents in Aligarh Archives, p. 54

Abbas, Asghar, Aligarh ke Asar us Sanadeed, Sir Syed Number, Farid Book Depot, Delhi, 2017, p. 760

54 For details of this debate see, Ahmad, Nazir, 'Sir Syed Ahmad Khan's Works on Archaeology Entitled Athar-us-Sanadid: A Study', published in Sir Syed Ahmad Khan: A Centenary Tribute, ed. Asloob A. Ansari, Adam Publishers, Delhi, 2001, pp. 128-153
} 
Jhss, Vol. 10, No. 1 , January to June, 2019

History of Indian civilization were just beginning to take roots in the mid-19th century and at that time Sir Syed's work was a pioneering one. He was working on aspects of historical archaeology even before Cunningham and John Marshall. Even before the development of Archaeological Survey of India, Sir Syed was spanning historical structures with a measuring tape in his hand and historical context in his head, and for that, he needs to be credited as a historian, as an archaeologist and as a historical archaeologist. 


\section{References:}

Abbas, Asghar, Aligarh ke Asar us Sanadeed, Sir Syed Number, Farid Book Depot, Delhi, 2017

Ahmad, Nazir, 'Sir Syed Ahmad Khan's Works on Archaeology Entitled Athar-usSanadid: A Study', published in Sir Syed Ahmad Khan: A Centenary Tribute, ed. Asloob A. Ansari, Adam Publishers, Delhi, 2001

Cunningham, Alexander, Sir Alexander Cunningham and the beginnings of Indian archaeology, Dacca, Asiatic Society of Pakistan, 1966.

Elliot, H.M. and Dawson, J., History of India as told by its own Historians, Allahabad, Vol. 6

Hali, Khvajah Altaf Husain, Hayat-i-Javed : a biographical account of Sir Sayyid, translation, K.H. Qadiri \& David J. Matthews, Idarah-i -Adabiyat-i-Delli, Delhi, 1979

Harrington, J. C., 'Archaeology as an Auxiliary Science to American History', American Anthropologist, New Series, Vol. 57, No.6, Dec. 1955, pp.1121-1130.

Khan, Sir Syed Ahmad, Asar-us-Sanadeed, Sir Syed Academy, Aligarh, 2007

Lorenz, Chris, 'Scientific/Critical Historiography', in: Aviezer Tucker (ed.), Blackwell Companion to Philosophy of History and Historiography, Blackwell: Oxford 2008

Malik, Z.U., 'Historical Writings of Sir Syed Ahmad Khan on the Indian Revolt, 18571859', published in Sir Syed Ahmad Khan: A Centenary Tribute, ed. Asloob A. Ansari, Adam Publishers, Delhi, 2001

Marshall, John, A guide to Taxila, Cambridge University Press, London, 1960.

Mehta, R.N., Medieval Archaeology, Delhi, 1979

Naim, C. M., 'Syed Ahmad and His Two Books Called 'Asar-al-Sanadid', Modern Asian Studies, 2010, pp.1-40

Selected Documents in Aligarh Archives, ed. Yusuf Husain Khan, Aligarh, 1977

Siddiqui, Iqtidar Husain, 'Sir Syed Ahmad Khan's Approach to History and History Writing', published in Sir Syed Ahmad Khan: A Centenary Tribute, ed. Asloob A. Ansari, Adam Publishers, Delhi, 2001 
Jhss, Vol. 10, No. 1 , January to June, 2019

Singh, Upinder, The Discovery of Ancient India: Early Archaeologists and the Beginnings of Archaeology, Permanent Black, Delhi, 2004

Troll, Christian W., 'A Note on an Early Topographical Work of Sayyid Ahmad Khan: Asar Al Sanadid', The Journal of the Royal Asiatic Society, 1972, No. 2 